\title{
Morphometric Evidences for Regional Variation in Potential of Neural Plasticity
}

\author{
Evidencias Morfométricas de Variación Regional \\ en Potencial de Plasticidad Neural
}

\author{
"Seyyed Amirhossein Fazeli; "Ali Davarian; **Naser Behnampour \& *Mohammad Jafar Golalipour
}

FAZELI, S. A.; DAVARIAN, A.; BEHNAMPOUR, N. \& GOLALIPOUR, M. J. Morphometric evidences for regional variation in potential of neural plasticity. Int. J. Morphol., 24(2):181-186, 2006.

SUMMARY: The neural plasticity showing the ability of nervous system to change its structure and function is a well-documented fact. However regional variation within a CNS structure to undergo plastic changes has been shown by limited studies.

Along medial-lateral sequences of parasagittal sections, the molecular layer thickness of primary fissure borderlands in rat cerebellar left hemisphere was studied to assess the regional difference in plasticibility.

Despite the homogeneity of cerebellar histology, this study showed that there is a significant interlobular difference between ML thicknesses of Prf borderlands. In addition, it revealed that the thickness alters in a significant trend within each borderland.

The quantitative heterogeneity of cerebellar architecture such as variation of cortical thickness may provide some evidences to show that different regions of a homogenous cortex, even two adjacent borderlands and areas within them, can have different potentials for plasticity.

KEY WORDS: Plasticibility; Molecular layer; Primary fissure; Cerebellum; Rat.

\section{INTRODUCTION}

Neural plasticity showing the ability of nervous system to change its structure and function is a welldocumented fact. (Diamond, 2001) Indeed, this is the basis of normal learning and memory. (Diamond; Crepel et al., 1996).

Alterations of cortical thickness as well as other structural changes were studied by some researchers to show the neural plasticity in response to different exposures (Diamond). Despite these abundant attempts showing dynamism of neural tissues, regional variation within a CNS structure to undergo plastic changes which may be called as "regional plasticibility" was shown by limited studies (Anderson et al., 1994, 2002).

The logic way to show the difference between the plasticibility of two regions is to compare their plastic changes following an exposure. However, the results of such a comparison may be exposure-dependent and can be differ with each exposure (Anderson et al., 2002).Therefore, to have a constant scope of regional difference in plasticibility, the tissue characteristics such as cortical thickness which may reflect the ability for plastic changes can be compared.

In this study, the two lobular borderlands of primary fissure (Prf) in rat cerebellar left hemisphere were the subjects of the comparison. The thickness of molecular layer (ML) which is a synaptic zone and abundant of neural processes was chosen as comparing characteristic between the borderlands (Kiernan, 1998). Therefore, along a medial-lateral range of study, the lack or presence of difference between two borderlands (Interlobular variation) and within them (Intralobular variation) were assessed. (Fig.1).

* Department of Anatomy, Faculty of Medicine, Gorgan University of Medical Sciences, Gorgan, Iran.

*** Department of Research, Gorgan University of Medical Sciences, Gorgan, Iran. 


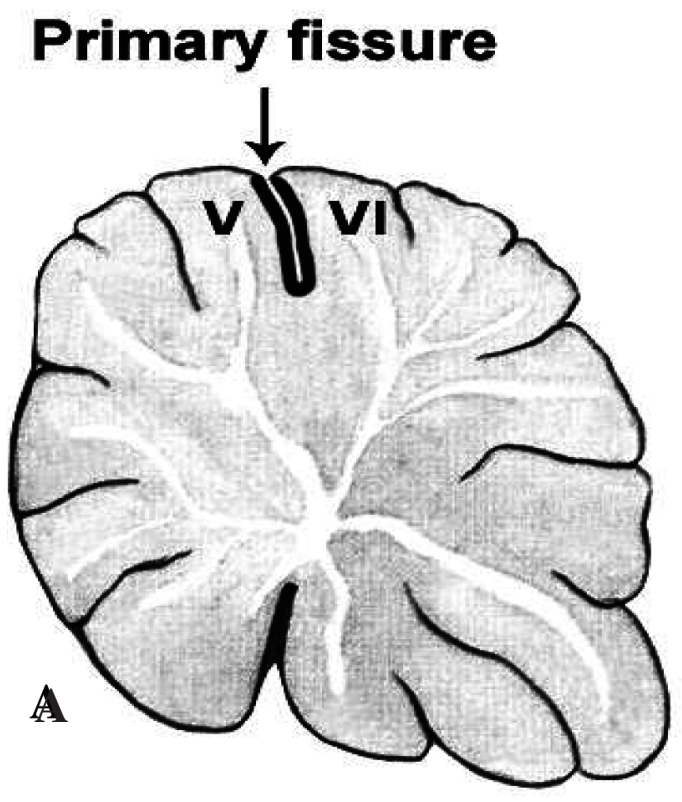

Fig. 1. Morphologic arrangment of rat cerebellum in a parasagittal section. A) The lobular borderlands of primary fissure were the area of study. (darkened area); V and VI: Cerebellar lobules V and VI. B) By a lateral-medial sequence of parasagittal sections $(\rightarrow)$, the thickness of molecular layer was studied in the borderlands of primary fissure. The measurements were restricted to stricts of the borderlands situated between summit (s) and bottum (b) of the fissure.

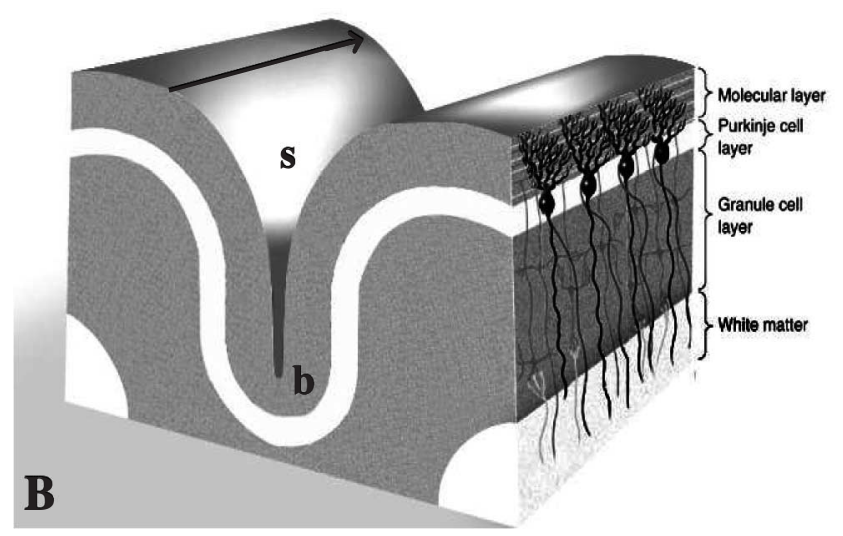

\section{MATERIAL AND METHOD}

This study was performed on two 6-week male Albino Wistar rats (E1 and E2) bought from Iranian Pasteur Institute. Both experiments were kept in same animal house with a non-enriched environment, 12 hours light/12 hours dark cycle, standard food regimen and water ad libitum.

After 18 weeks of keeping, the 24-week experiments were anesthetized by chloroform inhalation and killed with cervical dislocation. The skulls were dissected and cerebella were taken. To fix them, they were emerged in Clark solution for 48 hours. After fixation, the left hemispheres of each of two cerebella were separated from reminder at their junction with relevant vermises. The hemispheres were embedded in paraffin and $6 \mu \mathrm{m}$ parasagittal serial sections were prepared from each of them.

For a simple random selection, every 3-5 sections of each hemisphere were mounted on a glass slide. Consequently, a lateral-medial series of slides contained the parasagittal serial sections were provided for each hemisphere. As the count of sections mounted on the slides was variable between 3 to 5 sections, no equal interval was put in the lateral-medial position of the slides which is necessary in a simple random selection. Finally, the slides with numbers of 50, 60, 70, 80, 90, 100 and 110 for E1 and $50,60,70,80$ and 90 for E2 were selected.

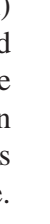


other using independent sample T-test. The significance was set at $\mathrm{p} \leq 0.05$.

To determine the relationship between ML thickness and lateral-medial position within the borderlands by the regression methods, in addition to normality of data distribution, the constancy of their variances was confirmed. Consequently, the different regression models such as linear, exponential, logarithmic, inverse, power and etc showing ML thickness in a lateral-medial transition within the borderlands were fitted.

\section{RESULTS}

The mean thicknesses of Prf borderlands in each of experiments were summarized in Table I. As shown in this table, in both experiments, the Molecular layer of borderland VI was significantly thicker than the corresponding layer of borderland V ( $\mathrm{p} \leq 0.0009)$. Also, the same finding was found with combined values of the experiments. $(\mathrm{p} \leq 0.0009)$.
Table I. Mean thicknesses of Molecular layer in Prf borderlands of the experiments.

\begin{tabular}{llr}
\hline & Borderla nd V & Borderla nd VI \\
Experiment 1 & $40.44(6.95,0.26) 1$ & $49.43(10.50,0.41)$ \\
Experiment 2 & $41.53(8.25,0.49)$ & $45.57(13.57,0.78)$ \\
Total & $40.75(7.35,0.23)$ & $48.19(11.71,0.38)$ \\
\hline $1 . \mu \mathrm{m}(\mathrm{SD}, \mathrm{SEM})$ & &
\end{tabular}

The scatter diagrams showing the lateral-medial transition of ML thickness in Prf borderlands were drawn for each experiment where the horizontal axis is representative of the distance that each section had from the lateral extreme of left hemisphere and vertical axis shows the relevant thicknesses measured in each sections. (Figs. 2, $3,4,5)$ Although all the fitted regression models were significantly appropriate $(\mathrm{p} \leq 0.05)$; but as the linear model is easier to understand, it was chosen to associate the diagrams.

In Fig. 2, it is shown that in a lateral-medial trial, the closer to vermis, the thicker were the layers. The slope of the line is positive and the model was significantly appropriate. $\left(\mathrm{p} \leq 0.0009 ; \mathrm{R}^{2}=0.035\right)$

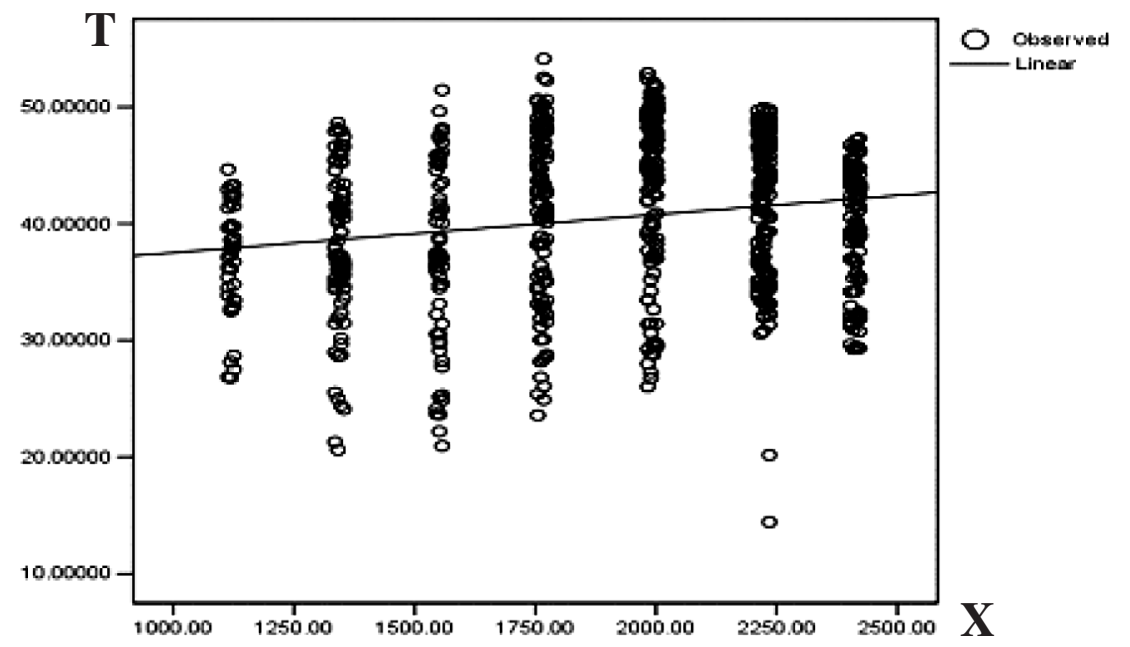

Fig. 2. Lateral-medial transition of ML thickness in Prf borderland V of E1. The equation of fitted line was $\mathrm{T}=34.249+0.003 \mathrm{x}$ with $\mathrm{p} \leq 0.0009$ and $\mathrm{R}^{2}=0.035$.

$\mathrm{T}$ : ML thickness $(\mu \mathrm{m}) ; \mathrm{X}$ : lateral-medial position $(\mu \mathrm{m})$.

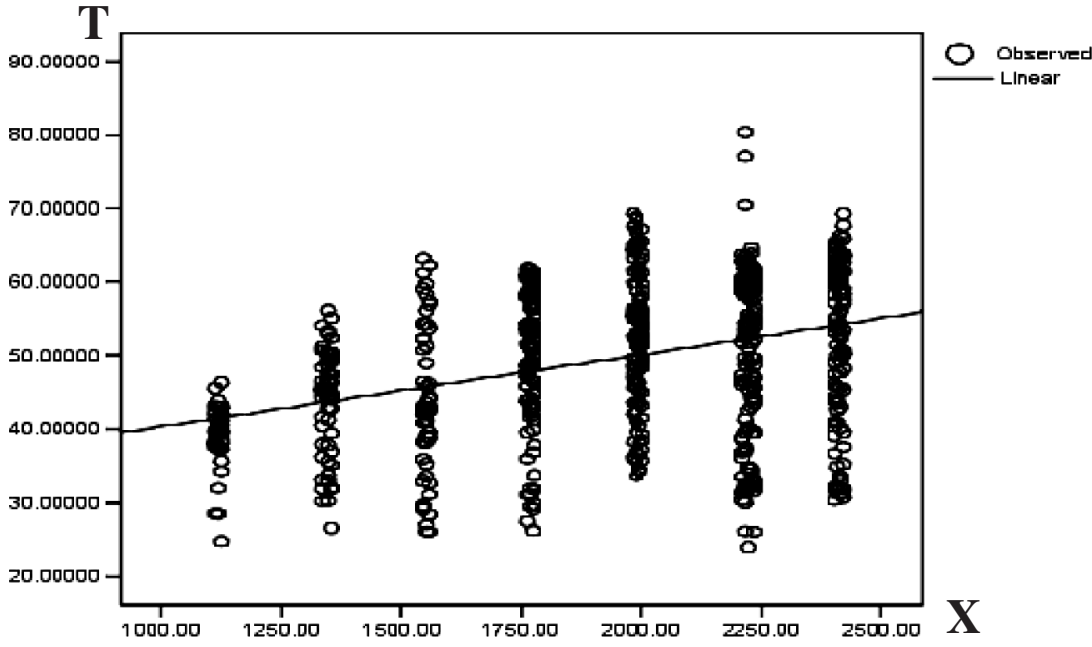

Fig. 3. Lateral-medial transition of ML thickness in Prf borderland VI of E1. The equation of fitted line was $\mathrm{T}=30.507+0.010 \mathrm{x}$ with $\mathrm{p} \leq 0.0009$ and $\mathrm{R}^{2}=0.129$.

T: ML thickness $(\mu \mathrm{m}) ; \mathrm{X}$ : lateral-medial position $(\mu \mathrm{m})$. 
Fig. 3 shows that the ML thickness of Prf borderland VI of E1 changes in the same manner as the borderland V. The fitted equation for this diagram has a positive coefficient showing the increase in mean ML thicknesses of borderland VI from lateral extreme toward vermis. $\left(\mathrm{p} \leq 0.0009 ; \mathrm{R}^{2}=\right.$ $0.129)$.

Comparison between the fitted equations showed that the coefficient for borderland VI equation was more than the same one for borderland V. (0.010 Vs 0.003).
In E2, as shown in Figs. 4 and 5, the ML thicknesses of both borderlands clarify a decreasing lateral-vermial transition.

A significant linear equation was fitted for each of diagrams. $\left(\mathrm{p} \leq 0.0009 ; \mathrm{R}^{2}=0.106\right.$ for borderland $\mathrm{V}$ and $\mathrm{p} \leq 0.0009 ; \mathrm{R}^{2}=0.075$ for borderland VI)

Comparison between the fitted equations showed that the coefficient for borderland VI was more than the same for borderland V.
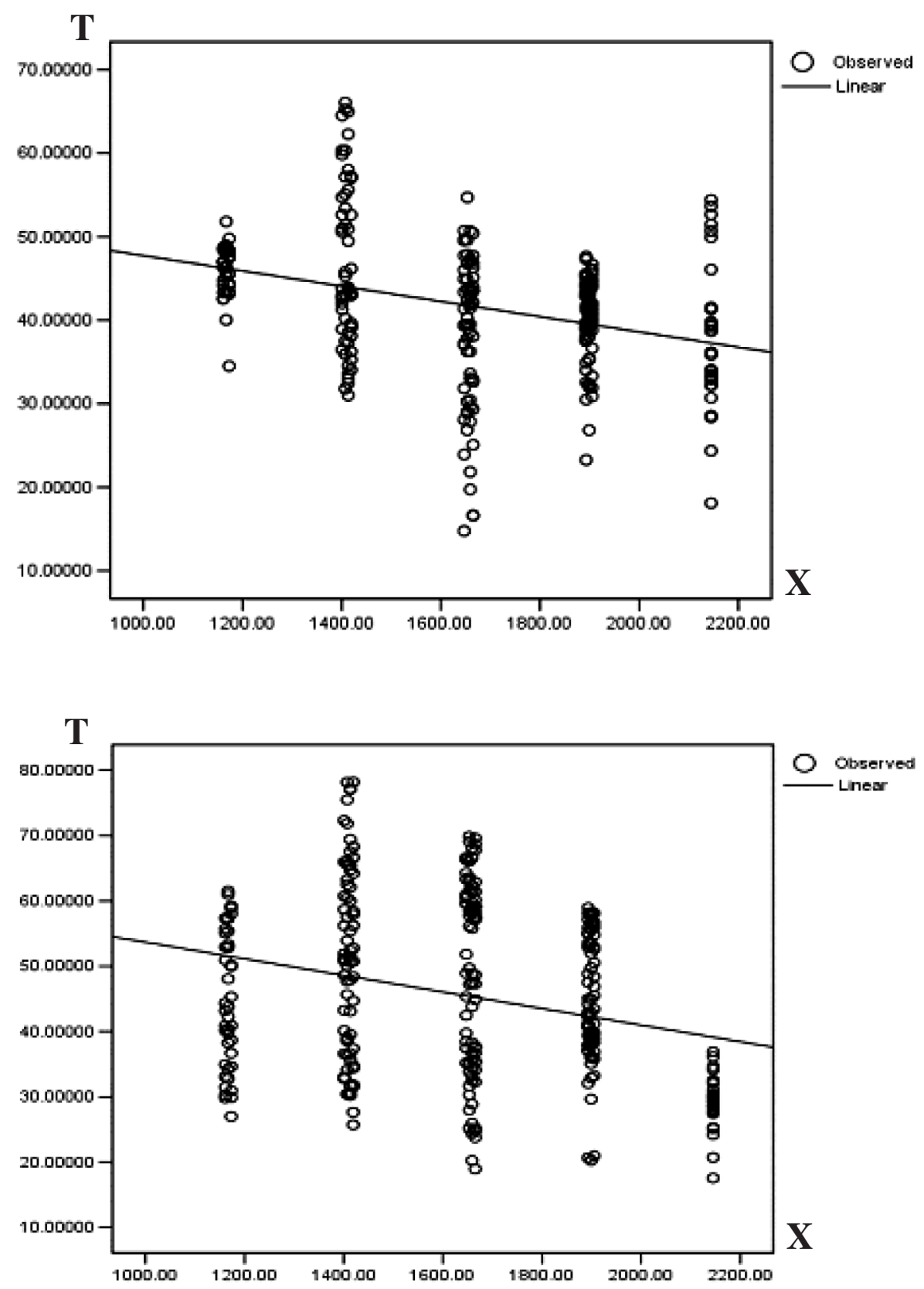

Fig. 4. Lateral-medial transition of ML thickness in Prf borderland $\mathrm{V}$ of E2. The equation of fitted line was $\mathrm{T}=56.868-0.009 \mathrm{x}$ with $\mathrm{p} \leq 0.0009$ and $\mathrm{R}^{2}=0.106$.

T: ML thickness $(\mu \mathrm{m})$;

$\mathrm{X}$ : lateral-medial position $(\mu \mathrm{m})$.
Fig.5: Lateral-medial transition of ML thickness in Prf borderland VI of E2. The equation of fitted line was $\mathrm{T}=66.371-0.013 \mathrm{x}$ with $\mathrm{p} \leq 0.0009$ and $\mathrm{R}^{2}=0.075$.

T: ML thickness $(\mu \mathrm{m})$;

$\mathrm{X}$ : lateral-medial position $(\mu \mathrm{m})$. 


\section{DISCUSSION}

Despite the homogeneity of cerebellar histology, this study showed that there is a significant interlobular difference between ML thicknesses of Prf borderlands. In addition, by a lateral-medial study of parasagittal sections, it revealed that the thickness alters in a significant trend within each borderland showed the intralobular variation.

The cytoarchitecture of molecular layer is designed in a way made it as a modifier structure. Indeed, by inhibitory interneurons like basket and satellite cells associated by dendrites of Golgi cells, it can modify any exciting volley entering through parallel and climbing fibers to Purkinje cells. This fine tuning task of molecular layer between the inputs of Purkinje cells and Purkinje output to deep nuclei play an important role in cerebellar function (Kiernan).

Long-term depression (LTD) of synaptic transmission at parallel fiber-Purkinje cell synapses is thought to be a cellular substrate of synaptic plasticity in the cerebellum. This use-dependent change in synaptic efficacy is induced by conjunctive stimulation of parallel and climbing fibers (Crepel et al.,). In concert with LTD at excitatory synapses of Pukinje fiber, a robust and long-lasting potentiation of inhibitory synaptic transmission is induced following stimulation of excitatory climbing fibers, that was termed "rebound potentiation" (RP) (Kano, 1996).

As the thickness can reflect the neuronal content, the homogenous areas with different thicknesses may have difference in quantity of histologic facilities. Therefore, it can be reasonably postulated that, in mentioned areas such as Prf borderlands, neurons like Purkinje cells can be trapped by different compositions of presynaptic fibers and, consequently, show synaptic heterogeneity even have no difference in postsynaptic receptors (Lambolez et al., 1992).

Excitatory and inhibitory populations (parallel/ climbing fibers Vs basket/satellite and Golgi cells) play differently in LTD and RP (Crepel et al.; Kiernan and Kano). Hence, as areas with different thicknesses may have difference in neuronal populations, it can be theorized that these mechanisms share differently in plasticity of various cerebellar regions.

Found trends and equations can help guide to develop a computer model integrating the morphometric characteristics of rat cerebellar hemisphere. Such model can simulate an artificial tissue displaying the plastic changes of different cerebellar regions in response to different exposures as well as pathologic processes and therapeutics.

\section{CONCLUSION}

Based on these postulated differences in mechanisms of neural plasticity, the quantitative heterogeneity of cerebellar architecture such as variation of cortical thickness may provide some evidences to show that different regions of a homogenous cortex, even two adjacent borderlands and areas within them, can have different potentials for plasticity.

ACKNOWLEDGMENTS: The authors appreciate the financial support provided by Gorgan University of Medical Sciences and feel indebted to all colleagues who helped us in this project.

FAZELI, S. A.; DAVARIAN, A.; BEHNAMPOUR, N. \& GOLALIPOUR, M. J. Evidencias morfométricas de variación regional en potencial de plasticidad neural. Int. J. Morphol., 24(2):181-186, 2006.

RESUMEN: Aunque la plasticidad neural muestra la capacidad del sistema nervioso para cambiar su estructura y función, lo cual es un hecho bien documentado, pocos estudios han mostrado la variación regional, dentro de la estructura del sistema nervioso central para sufrir cambios plásticos.

A través de disecciones parasagitales, secuenciadas de medial a lateral, se estudió el grosor de la capa molecular, en el límite de la cisura primaria de hemisferio izquierdo del cerebelo, de ratas, con el propósito de evaluar las diferencias regionales en plasticidad.

A pesar de la homogeneidad de la histología cerebelar, el estudio mostró que hay una diferencia interlobular significativa entre el grosor de la capa molecular en el límite de la fisura prima. Agregado a ello, fue revelado que los cambios de grosor tienen una tendencia significativa dentro de cada límite.

La heterogeneidad cuantitativa de la arquitectura cerebelar, tal como la variación en el grosor cortical, puede proveer algunas evidencias que muestran que regiones diferentes de un corte homogéneo, aún de límites y áreas adyacentes dentro del mismo, pueden tener diferentes potenciales para plasticidad. 


\section{REFERENCES}

Anderson, B. J.; Eckburg, P. B. \& Relucio, K. I. Alterations in the thickness of motor cortical subregions after motor-skill learning and exercise. Learning and Memory 9(1):1-9, 2002.

Anderson, B. J.; Li, X.; Alcantara, A.; Isaacs, K.; Black, J. \& Greenough, W. T. Glial hypertrophy is associated with synaptogenesis following motor-skill learning, but not with angiogenesis following exercise. Glia, 11:73-80, 1994.

Crepel, F.; Hemart, N.; Jaillard, D. \& Daniel, H. Cellular mechanisms of long-term depression in the cerebellum. Behavioral and Brain Sciences 19(3):347-53, 1996.

Diamond, M. C. Response of the brain to enrichment. An. Acad. Bras. Cienc., 73(2):211-20, 2001.

Kano, M. Long-lasting potentiation of GABAergic inhibitory synaptic transmission in cerebellar Purkinje cells: Its properties and possible mechanisms. Behavioral and Brain Sciences, 19(3):354-61, 1996.

Kiernan, J. A. Cerebellum. In: Barr's the human nervous system-An anatomical viewpoint. $7^{\text {th }}$ ed., New York: Lippincott-Raven Publishers, 1998. pp.195-213.

Lambolez, B.; Audinat, E.; Bochet, P.; Crepel, F. \& Rossier, J. AMPA receptor subunits expressed by single Purkinje cells. Neuron, 9:247-58, 1992.
Correspondence to:

Dr. Seyyed Amirhossein Fazeli

Department of Anatomy,

Faculty of Medicine,

Gorgan University of Medical Sciences,

Gorgan-IRAN

Postal address:

$\mathcal{N}(0.4$, Farmandari alley,

Emam Khomeini Ave,

Kordkuy City,

Postal Code: 4881636874

Golestan Province - IRAN

Telephone: $+98(173) 3222995$

$+989111714070$

Fax number: :+98(171)4421657

$+98(171) 4425165$

Email address: glial61@yafioo.com

Received : 15-12-2005

Accepted: 22-02-2006 